Article

\title{
Remediation of Multiply Contaminated Ground via Permeable Reactive Barrier and Electrokinetic Using Recyclable Food Scrap Ash (FSA)
}

\author{
Dongchan Kim ${ }^{1}$ (D) and Junggeun Han ${ }^{2, *}$ \\ 1 Department of Civil Engineering Chung-ang University, Seoul 06974, Korea; hero081123@nate.com \\ 2 School of Civil and Environmental Engineering, Urban Design and Study, Chung-Ang University, \\ Seoul 06974, Korea \\ * Correspondence: jghan@cau.ac.kr
}

Received: 22 December 2019; Accepted: 6 February 2020; Published: 11 February 2020

Featured Application: This study was carried out using in-situ electrokinetic remediation which does not disturb the ground. The drawback of electrokinetic remediation is that precipitation occurs, and it interrupts the transport of the heavy metals. Therefore, a Permeable Reactive Barrier was filled with recyclable Foods Scrap Ash to increase the movement of the contaminant. Little research has been conducted into soils contaminated with heavy metals and organics. This study presents fundamental research about the remediation of ground with multiple contaminations and provides practical guidance in the remediation of contaminated ground.

\begin{abstract}
A study of the application of electrokinetic (EK) remediation and Permeable Reactive Barriers (PRB) using recyclable Foods Scrap Ash (FSA) in multiple contaminated soils was carried out. An FSA was chosen as a PRB fill material due to its highly efficient capacity for contaminant removal. Acetic acid and Brij30 were used as enhancers on copper and phenanthrene, respectively, to improve EK remediation performance in removing the heavy metal and organic contaminants. Copper adsorption in PRB was so substantial that the confirmed removal efficiency was $83.86-90.17 \%$ and the remaining amount was 105-212 mg. While a high removal efficiency of acetic acid was observed on copper in multiple contamination soils; the removal of phenanthrene was hardly detected and the recovery rate of the contaminant was low during pretreatment. Therefore; an additional study of pretreatment on the phenanthrene-contaminated kaolinite needs to be performed.
\end{abstract}

Keywords: electrokinetic (EK); Foods Scrap Ash (FSA); multiple contamination grounds; Permeable Reactive Barrier (PRB); phenanthrene; remediation

\section{Introduction}

Soil pollution has not been considered as serious as water and air pollution, but soil pollutions have deteriorated rapidly with the use of chemicals alongside economic growth [1-3]. Heavy metals contaminate the ground as persistent non-aqueous phase liquid (NAPL) contaminants that remain adsorbed onto soil particles. In addition, ground contamination caused by the rapid increase in the use of organic compounds has come to the fore as a serious social problem [4]. Representative contaminants include $\mathrm{Cu}, \mathrm{Pb}, \mathrm{Zn}$ and $\mathrm{Ni}$ from industrial activities (e.g., operating power plants or constructing the infrastructures) and BETX and TPH in aged gas stations in South Korea [5-8].

Soil pollution has not been seriously considered compared to water or air pollution in South Korea [1]. The effect of soil pollution cannot be simply determined because the mobility of the contaminants is restricted, and such contaminants are mainly transported by the ground water $[9,10]$. 
In addition, there is a substantial gap in time in which the contaminated groundwater leads to an outbreak resulting in a threat to human health. [11,12]. Soil hardly recovers once contaminated compared to other forms of environmental pollution, and it requires much more time and money. In particular, a consistent increase in annual food waste production due to improvements in quality of life and an increase in small families has resulted in resource-wasting and environmental pollution [13].

There are difficulties in remediating the contaminated ground, especially in processing the fine-textured soils that cannot be cleaned using general methods such as Pump and Treat or Soil Washing. The in-situ method is preferred to reduce excavation costs and ensure safety, and the electrokinetic (EK) remediation technique is an in-situ method that is appropriate for fine-textured soils. Electrophoresis and electroosmosis are the main mechanisms in heavy metal removal and organism purification, respectively [14,15].

EK remediation consists of installing electrodes and sending a low direct current (DC) current in an area with polluted soil to remove the contaminants (e.g., heavy metals and microorganisms) [16-18]. This study applied the more effective removal technique using a Permeable Reactive Barrier (PRB) that prevents the spread of contaminants and purifies them by inducing the adsorption, precipitation and decomposition with the reactant $[19,20]$.

In addition, the PRB technique was chargeable with recyclable food scrap ash (FSA) and exchangeable to discharge contaminants within the ground to the cathode. The adsorbent was installed at $75 \%(x / L)$ to the anode, near the precipitation boundary, to prevent precipitation by the hydroxyl ion and remove contaminants by applying an improver. The multiply contaminated soil was selected to includde heavy metal, copper and aromatic compounds with benzene rings, phenanthrene [5]. The remediation technique applied in this study was an economical and environmentally friendly purification technique. FSA was a recycled material resulted from the incineration of food waste, and it was used as an adsorbent in the treatment process. Finally, this study will be beneficial in developing an advanced remediation technique using recyclable FSA by characterizing the EK remediation of copper and phenanthrene in multiple contaminated ground.

\section{Materials and Experimental Methods}

\subsection{Materials}

\subsubsection{Soil Sample}

The sample used in the experiment consisted of visco-plastic clay (US commercial Kaolinite (Southeastern Clay Company, South Carolina, USA) with limited amount of foreign materials). For the EK remediation experiment, kaolinite with a low plasticity was more effective than the one with a high plasticity, containing distensible minerals and at the condition of less than $30 \%$ particles of a size smaller than $2 \mu \mathrm{m}$ [21]. Additionally, due to its high affinity to heavy metals, kaolinite becomes homogeneous in indoor experiments and remains stable as inactive clay even under changing water content [22]. It also has a relatively low cation-exchange capacity (CEC) to facilitate the characterization of EK remediation at a concentration of the contaminant with a fast enough reaction rate for the ion exchange. The material properties are described in Table 1.

Table 1. Material Properties of Soil.

\begin{tabular}{cccccccc}
\hline $\begin{array}{c}\text { Liquid } \\
\text { Limit }\end{array}$ & $\begin{array}{c}\text { Plastic } \\
\text { Limit }\end{array}$ & $\begin{array}{c}\text { Plastic } \\
\text { Index }\end{array}$ & $\begin{array}{c}\text { Specific } \\
\text { Gravity }\end{array}$ & $\begin{array}{c}\text { Passing } \\
\mathbf{0 . 7 5} \boldsymbol{\mu m}\end{array}$ & $\begin{array}{c}\text { CEC } \\
\text { (Cmol/kg) }\end{array}$ & $\begin{array}{c}\mathbf{p H} \text { at } \\
\mathbf{w}=\mathbf{4 0 0} \%\end{array}$ & USCS \\
\hline 62.21 & 41.82 & 20.39 & 2.6 & 100 & 7.24 & $4.5-5.5$ & CL \\
\hline
\end{tabular}

\subsubsection{Recyclable Adsorbent, FSA, Filled in the PRB}

The PRB method was selected to prevent the adsorption and the precipitation of heavy metal resulted from the interaction with the existing hydroxyl ions forming precipitates. The incinerated 
The test cell with the electrode reservoir installed at both ends consisted of a bubble tube and cylinder which made a free discharge via electroosmosis and measured the outflow discharge. The water level of the internal test cell remained consistently by injecting the improver through a Mariotte bottle and the carbon electrode was used.

\subsubsection{Batch Test}

A batch test was conducted using the adsorbent, FSA, to examine the adsorption of copper and phenanthrene. Copper was stirred at $200 \mathrm{rpm}$ for 5-80 $\mathrm{min}$ in a solution manufactured at 50-800 ppm, while phenanthrene was stirred at $150 \mathrm{rpm}$ for $12 \mathrm{~h}$ in an organic solution manufactured at 500-4500 ppm. Due to the difference in absorption capacity between the heavy metal (i.e., copper) and the organic compound (i.e., phenanthrene), each contaminant was analyzed with ICP (Inductively Coupled Plasma) and GC (Gas Chromatography) after the experiment was carried out under different conditions. The lab-scale experimental conditions are provided in Table 3.

Table 3. Batch Test Condition.

\begin{tabular}{ccccc}
\hline Pollution Material & Concentration $(\mathbf{p p m})$ & Contract Time & $\begin{array}{c}\text { Shaking Speed } \\
(\mathbf{r p m})\end{array}$ & $\begin{array}{c}\text { Mixture Rate } \\
(\mathrm{g} / \mathrm{mL})\end{array}$ \\
\hline Copper & $50,100,200,400,800$ & $\begin{array}{c}50,10,20,40,80 \\
(\mathrm{~min})\end{array}$ & 200 & $50: 1$ \\
\hline Phenanthrene & $\begin{array}{c}500,1000,2000,3000, \\
3500,4000,4500\end{array}$ & $12(\mathrm{hr})$ & 150 & $200: 1$ \\
\hline
\end{tabular}

\subsubsection{Cell Test}

EK remediation was conducted to characterize the contaminant removal in multiple contaminated ground with heavy metal and organic contaminants. Pollution concentrations of 1000 ppm phenanthrene and 500 ppm copper was mixed with methanol and DDW (Double Distilled Water) as a control condition and acetic acid and Brij30 were added as the improvers. Specifically, the phenanthrene contaminated solution was prepared using methanol as a solvent and the copper contaminated solution was prepared using copper nitrate powder $\left(\mathrm{Cu}\left(\mathrm{NO}_{3}\right)_{2}\right)$ in DDW. Kaolinite was used as a source of simulating the ground condition and it was contaminated with 1000 ppm with phenanthrene solution and dried in the shade. After drying, the pulverized kaolinite was applied to 500 ppm of copper contaminated soil at a water content of $60 \%$. Then, the contaminated kaolinite was installed in the cell in which the FSA was filled inside of PRB.

10 days of running time, $1 \mathrm{~V} / \mathrm{cm}$ of electric gradient, $\mathrm{PRB}$ located at $(\mathrm{x} / \mathrm{L})=0.75$ where acid and base frons are meet, and $0.05 \mathrm{M}$ acetic acid and $0.01 \mathrm{M}$ Brij30 were used [26]. The current density, the change in $\mathrm{pH}$ between the anode and cathode, and the outflow were measured during the experiment, while the other parameters (e.g., water content, residual contaminant concentration, and $\mathrm{pH}$ ) were analyzed after the completion of the experiment with the KSTM (Korea Standard Testing Method).

In this study, the cell test was conducted using the EK remediation technique to characterize the contaminant removal in the multiple contaminated ground with heavy metals and organic contaminants. The PRB and improvers were used to solve the precipitation problem that occurred in the previous EK remediation technique, and the FSA was applied as the filling material for the PRB to induce the adsorption of the contaminants. Hereby, the removal characteristics of the heavy metals and organic contaminants analyzed in fine-textured ground with multiple contamination. The EK experiments were performed in the lab and the test conditions are provided in Table 4. 
Table 4. EK Test Condition.

\begin{tabular}{|c|c|c|c|c|c|c|c|}
\hline \multirow{5}{*}{$\begin{array}{l}\text { Duration } \\
\text { (Day) }\end{array}$} & \multicolumn{2}{|l|}{ Fixed Factor } & \multicolumn{5}{|c|}{ Variable Factor } \\
\hline & \multirow{4}{*}{$\begin{array}{l}\text { Electric } \\
\text { Gradient } \\
(\mathrm{V} / \mathrm{cm})\end{array}$} & \multirow{4}{*}{$\begin{array}{c}\text { PRB } \\
\text { location } \\
(\mathrm{x} / \mathrm{L})\end{array}$} & \multicolumn{5}{|c|}{ Pollution Material (ppm) } \\
\hline & & & Copper & Phenanthrene & \multicolumn{3}{|c|}{ Mix (Copper and Phenanthrene) } \\
\hline & & & 500 & 1000 & \multicolumn{3}{|c|}{500 and 1000} \\
\hline & & & \multicolumn{5}{|c|}{ Solution } \\
\hline \multirow{3}{*}{10} & \multirow{3}{*}{1} & \multirow{3}{*}{0.75} & DDW & DDW & DDW & Acetic $0.05 \mathrm{M}$ & Brij30 0.01 M \\
\hline & & & \multicolumn{5}{|c|}{ Test No. } \\
\hline & & & Exp. 1 & Exp. 2 & Exp. 3 & Exp. 4 & Exp. 5 \\
\hline
\end{tabular}

\section{Result and Discussion}

\subsection{Batch Experiments}

The results of the FSA batch test in the adsorption of copper and phenanthrene are described in Figures 2 and 3. The maximum adsorptions with FSA were approximately $28 \mathrm{mg} / \mathrm{g}$ of copper and $890 \mathrm{mg} / \mathrm{g}$ of phenanthrene, respectively, indicating the greater adsorption capacity of FSA for phenanthrene, which was approximately 30 times higher than the adsorption of copper. Previous copper adsorption isotherms are described with a semi-log in Figure $2 b$ as well as in Figure $3 b$. As a result of linearizing the adsorption isotherm models using the Langmuir and Freundlich models in Figures 2a and 3a, the Langmuir model predicted the adsorption of the heavy metals and the organic compounds better than Freundlich model. Similarly, the semi-log scale (e.g., Figures $2 b$ and $3 b$ ) also shows a better fit in the Langmuir model.

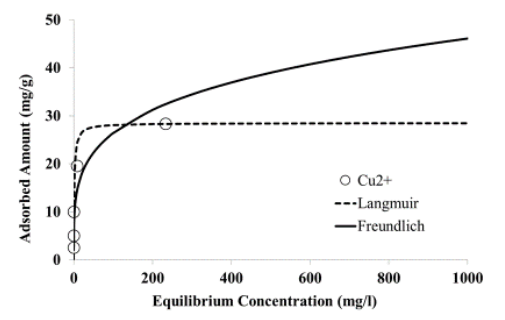

(a)

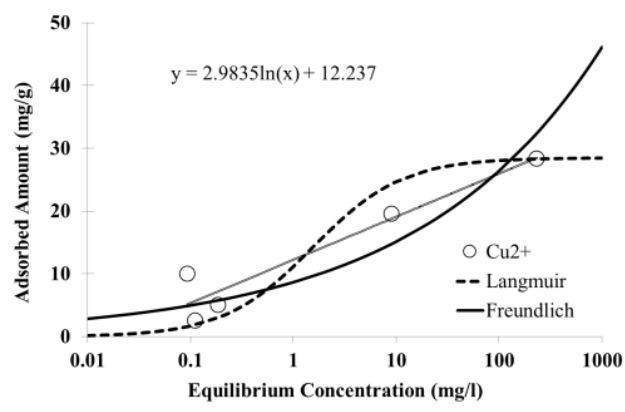

(b)

Figure 2. Comparison of the experimental results, with the amount of Copper adsorbed obtained using Langmuir and Freundlich isotherms. (a) General Graph; (b) Log Graph.

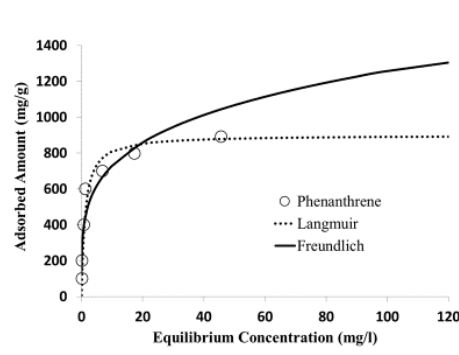

(a)

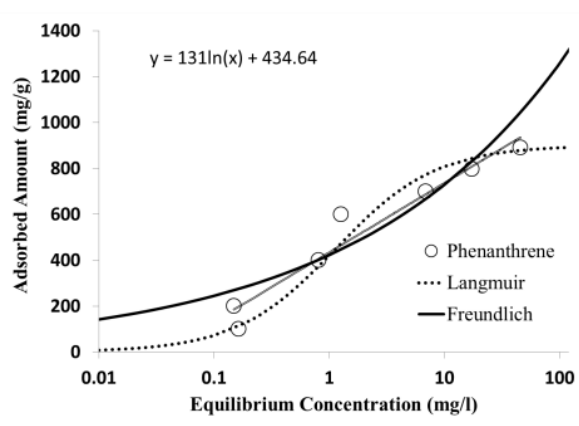

(b)

Figure 3. Comparison of the experimental results, with the amount of Phenanthrene adsorbed obtained using Langmuir and Freundlich isotherms. (a) General Graph; (b) Log Graph. 
However, the undistinguishable parts in the adsorption isotherm graphs confirm initial part on basic graphs and the Langmuir and Freundlich models. Accordingly, the proper comparison including these undistinguishable parts was not successful in the adsorption isotherm, but it can be confirm through the semi-log scale.

\subsection{EK Remediation Experiments}

\subsubsection{Post-Experiment Water Content}

Figure 4 shows the post-experiment water content in the sample, which was determined from five separate ports upon completing the experiment. Each value of the water content in general was not much different from the initial value of $60 \%$; however, it tended to be at a point of $x / L=0.9$. Considering that the water content remained similar to that of the initial value, the movement of the improver within the soil was confirmed to be most active during the EK remediation.

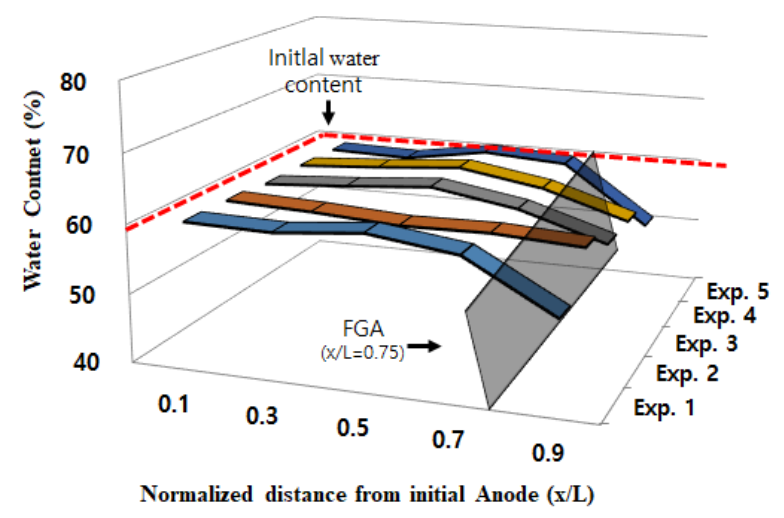

Figure 4. Water content within the sample of the test (Exp. 1-Exp. 5).

\subsubsection{Current Density and Outflow}

The pore water within the sample was found to move toward the cathode via electroosmosis. The outflow and current density of the improver are presented in Figure 5. To check the appropriate use of the improver per use, the result of the outflow was used to indicate whether the improver was smoothly injected into the sample.

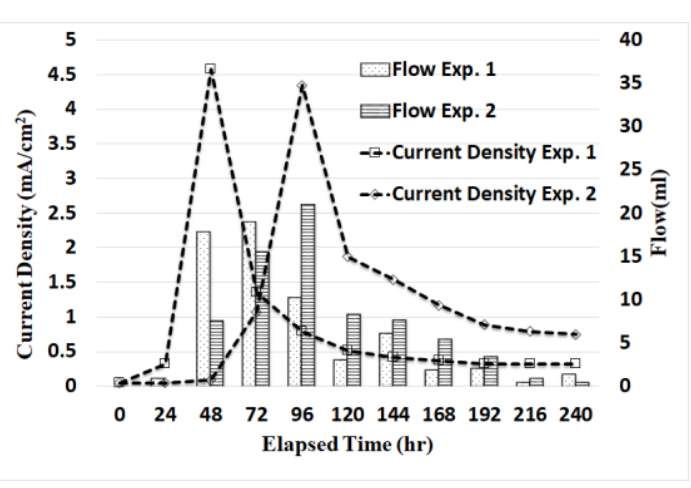

(a)

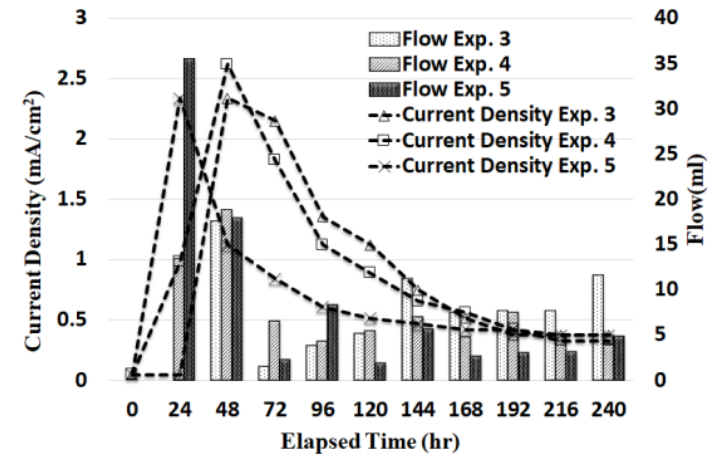

(b)

Figure 5. Result of the current density and total flow during the test (Exp. 1-Exp. 5). (a) Exp. 1 Exp. 2; (b) Exp. 3 Exp.5.

Figure 5a shows a comparison between the current density and outflow in the copperand phenanthrene-contaminated ground using DDW. The current density first increased in the copper-contaminated Exp. 1, and the outflow also increased following the increase in the current 
density before decreasing. The heavy metal copper ion responded with an EK phenomenon faster than the organic phenanthrene.

Figure $5 \mathrm{~b}$ describes the current density and outflow of the heavy metal and the organic compound with respect to the purification time determined by experiments using DDW, acetic acid and Brij30 as the improver in the multiple contaminated ground. The current density increased and then decreased after $48 \mathrm{~h}$, as shown in Exp. 1, and it reached a maximum with Brij30 after $24 \mathrm{~h}$. The outflow alongside the increase in the current density responded faster in Exp. 5 than in the other samples. The amount of outflow was presented in descending order as Brij30 > acetic acid > DDW, and the current density in the soil with multiple contaminations reached a peak in descending order, Brij30 $>$ acetic acid $>$ DDW. The amount of outflow hardly changed after $200 \mathrm{~h}$.

The initial current density and outflow appeared fairly quickly with Brij30 as the improver, but slowly decreased after $24 \mathrm{~h}$ with acetic acid in the ground with multiple contaminations. Selective contaminant removal and effective purification will be achieved in the ground with multiple contaminations if the more responsive Brij30 is applied at the early stage to remove the organic substance first and the improver is changed into acetic acid.

\subsubsection{PH and Residual Concentration in the Post-Experiment Sample}

Figure 6 shows the concentration and $\mathrm{pH}$ of the residual copper and phenanthrene measured in the post-experiment sample. As described in Figure 6a, the concentration of copper was detected to be slightly high at the point of $x / L=0.7$, which was relatively lower than the initial concentration of the contaminant.

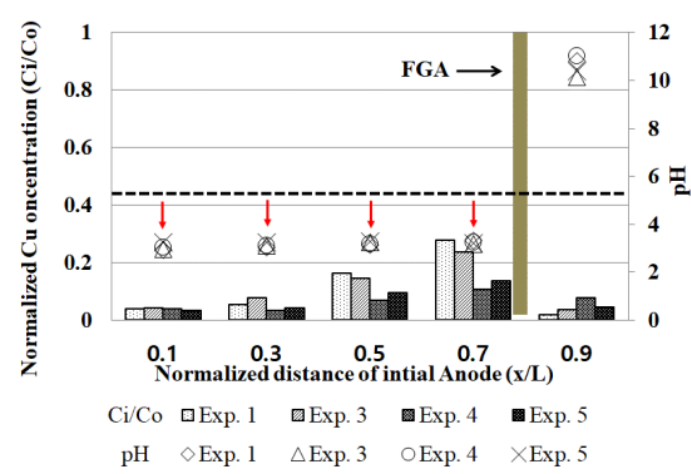

(a)

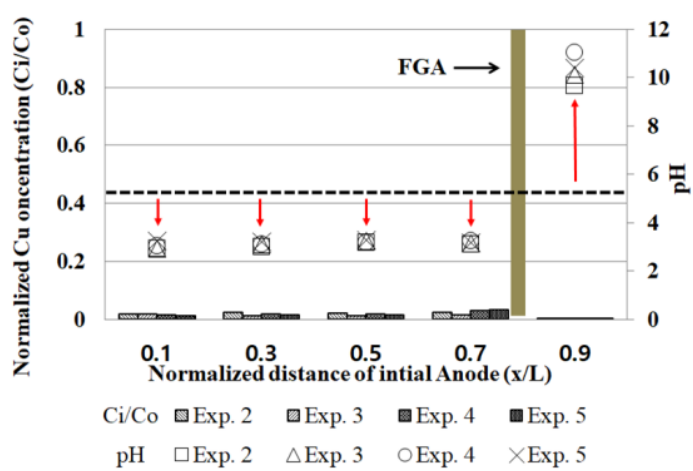

(b)

Figure 6. PH distribution within the sample of the test (Exp. 1-Exp. 5). (a) Copper; (b) Phenanthrene.

At this point, the concentration of the residual copper was detected as the lowest with the acetic acid improver, implying that the degree of purification in the contaminated ground was greater than that of other cases. In addition, the $\mathrm{pH}$ at $\mathrm{x} / \mathrm{L}=0-0.7$ was determined to be $2-4$, lower than $\mathrm{pH} 5$ where the precipitation of copper occurs, indicating that no precipitation occurred based on the results of a previous study [27]. However, as described in Figure 6b, the characteristics of the removal of phenanthrene were not clearly defined due to the low recovery of the pretreated contaminant sample. Therefore, further study of the pretreatment of phenanthrene might need to be conducted.

\subsubsection{Mass Balance}

The mass balance of the copper and organic phenanthrene was calculated upon completing the EK remediation experiment. The copper and phenanthrene extracts remained in the FSA and the filling material in the PRB were measured using the KSTM (Korea standard test method). The anode and the cathode of reservoir were measured and the mass balance of the copper was detected to be $91.53 \%, 91.58 \%, 93.90 \%$ and $95.71 \%$ in Exp. 1, 3, 4 and 5, respectively, while that of phenanthrene was hardly detected. The results are provided in Table 5. The amount and percentage of copper 
adsorbed in the FSA ranged from $105 \mathrm{mg}$ to 121 (i.e., $73 \%$ to $84 \%$, respectively) and the best removal of the copper was achieved with the acetic acid improver. Table 6 shows that the mass balance of phenanthrene was hardly detected, and this was because of the low recovery rate of phenanthrene in kaolinite, based on the results of study by Elektorowicz et al. [28] and Kang [29]. Therefore, further study of the pretreatment of phenanthrene may be needed to clarify the current results. Figure 7 shows that a certain amount of heavy metal remained in the contaminated sample, with reservoir and outflow confirming a large amount of copper remained in the FSA. However, phenanthrene was hardly detected and was unidentifiable.

Table 5. Mass balance of copper removed.

\begin{tabular}{|c|c|c|c|c|c|c|c|}
\hline \multirow[t]{2}{*}{ Test No. } & \multirow{2}{*}{$\begin{array}{c}\text { Initial } \\
\text { Amount of } \\
\text { Copper (mg) }\end{array}$} & \multirow{2}{*}{$\begin{array}{l}\text { Residual } \\
\text { in the Bed } \\
(\mathrm{mg})\end{array}$} & \multirow{2}{*}{$\begin{array}{l}\text { PRB (FSA) } \\
\quad(\mathrm{mg})\end{array}$} & \multirow{2}{*}{$\begin{array}{c}\text { Amount } \\
\text { Removed by } \\
\text { EOF (mg) }\end{array}$} & \multicolumn{2}{|c|}{$\begin{array}{l}\text { Residual Amount in } \\
\text { Reservoir (mg) }\end{array}$} & \multirow{2}{*}{$\begin{array}{c}\text { Mass } \\
\text { Balance } \\
(\%)\end{array}$} \\
\hline & & & & & (+) Anode & (-) Cathode & \\
\hline Exp. 1 & 144 & 23.24 & 105.88 & 0.45 & 2.17 & 0.04 & 91.53 \\
\hline Exp. 3 & 144 & 22.24 & 108.62 & 0.21 & 0.75 & 0.02 & 91.58 \\
\hline Exp. 4 & 144 & 16.70 & 121.12 & 0.11 & 1.29 & 0.06 & 93.90 \\
\hline Exp. 5 & 144 & 14.15 & 116.98 & 0.35 & 6.27 & 0.04 & 95.71 \\
\hline
\end{tabular}

Table 6. Mass balance of phenanthrene removed.

\begin{tabular}{|c|c|c|c|c|c|c|c|}
\hline \multirow[t]{2}{*}{ Test No. } & \multirow{2}{*}{$\begin{array}{c}\text { Initial Amount of } \\
\text { Phenanthrene } \\
\text { (mg) }\end{array}$} & \multirow{2}{*}{$\begin{array}{c}\text { Residual } \\
\text { in the Bed } \\
\text { (mg) }\end{array}$} & \multirow{2}{*}{$\begin{array}{l}\text { PRB (FSA) } \\
\quad(\mathrm{mg})\end{array}$} & \multirow{2}{*}{$\begin{array}{c}\text { Amount } \\
\text { Removed by } \\
\text { EOF (mg) }\end{array}$} & \multicolumn{2}{|c|}{$\begin{array}{l}\text { Residual Amount in } \\
\text { Reservoir (mg) }\end{array}$} & \multirow{2}{*}{$\begin{array}{c}\text { Mass } \\
\text { Balance } \\
(\%)\end{array}$} \\
\hline & & & & & (+) Anode & (-) Cathode & \\
\hline Exp. 2 & 288 & 3.86 & 0.00075 & N.D & N.D & N.D & 1.34 \\
\hline Exp. 3 & 288 & 4.22 & 0.00025 & N.D & N.D & N.D & 1.47 \\
\hline Exp. 4 & 288 & 6.65 & 0.00075 & N.D & N.D & N.D & 2.31 \\
\hline Exp. 5 & 288 & 6.21 & 0.00175 & N.D & N.D & N.D & 2.16 \\
\hline
\end{tabular}

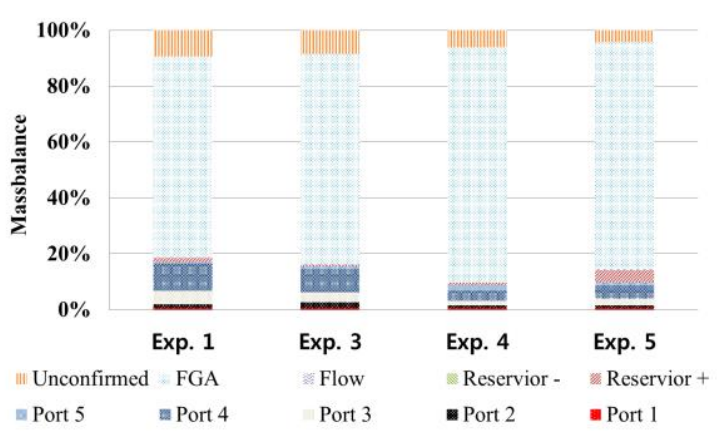

(a)

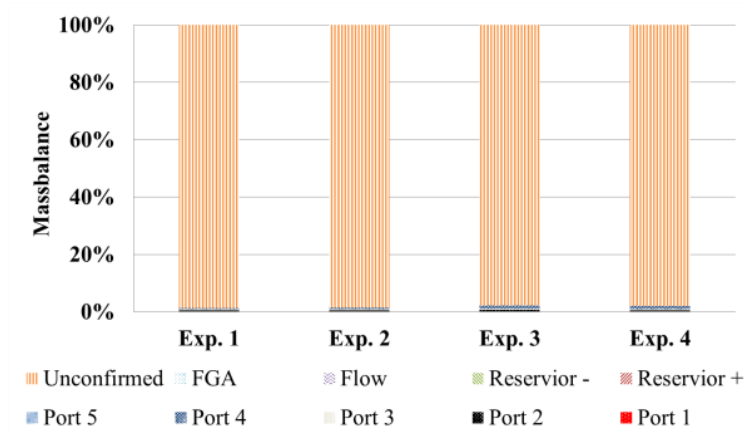

(b)

Figure 7. Mass Balance. (a) Copper; (b) Phenanthrene.

\section{Conclusions}

In this study, soil contaminants were removed by applying PRB filled with eco-friendly FSA and the improved EK remediation technique to ground with multiple contaminations. A comparison between the previous and log-transformed adsorption isotherms showed that the characteristics of copper and phenanthrene adsorption were matched better with the adsorption isotherm model by Langmuir. The overall adsorption isotherm might be confirmed using the semi-log transformation of those parts that were unidentifiable using a previous model. In addition, FSA, one of the by-products of food waste, was determined to be appropriate for use as a PRB filling material due to its highly efficient capacity to remove contaminants.

Acetic acid and Brij30 were used to improve the movement of contaminants within the ground and, ultimately, to improve the efficacy of the EK technique to treat heavy metals and organic compounds. 
The outflow increased as the initial value of the current increased and, thereafter, tended to decrease in a consistent degree over time. This indicates that the movement of the contaminants improved through the smooth introduction of the improver. If Brij30 with a high initial current density and responsiveness to the outflow was used after using the acetic acid, the heavy metal might be removed via selective purification involving the use of acetic acid as an improver after the purification of the initial organic contaminants. In addition, the water content of the post-experiment sample was maintained as the initial water contents, $60 \%$, and the movement of the improver was determined to be smooth during the EK remediation. A substantial change in the current and outflow reaction of the ionized heavy metal copper suggested rapid heavy metal removal.

The FSA adsorption was 105-212 mg after the experiment in the heavy metal copper-contaminated ground. The use of acetic acid as the improver was confirmed to be appropriate in Exp. 4 which used the acetic acid as an improver in the copper adsorbed to the FSA. Accordingly, acetic acid might be a safe and economical improver, maintaining the stability of current density while biodegrading. However, phenanthrene was hardly detected and was unidentifiable due to its low recovery rate in kaolinite. Therefore, pretreatment in the phenanthrene-contaminated kaolinite requires further study.

Author Contributions: All the authors contributed to this study. J.H.: conceptualization, funding acquisition, project administration, supervision, writing of review and editing; D.K.: investigation, formal analysis, writing of the original draft. All authors have read and agreed to the published version of the manuscript.

Funding: This research was supported by the Chung-Ang University Excellent Student Scholarship in 2012 and a grant from the National Research Foundation (NRF) of Korea, funded by the Korea Government (MSIP) (NRF-2019R1A2C2088962).

Conflicts of Interest: The authors declare no conflict of interest.

\section{References}

1. Environment, Purification of Pollution Guideline; Envoronment of Korea: Sejong-si, Korea, 2007.

2. Awad, Y.M.; Kim, S.C.; Abd EI-Azeem, S.A.M.; Kim, K.H.; Kim, K.R.; Kim, K.J.; Jeon, C.; Lee, S.S. Veterinary antibiotics contamination in water, sediment, and soil near a swine manure composting facility. Environ. Earth Sci. 2014, 71, 1433-1440. [CrossRef]

3. Tang, Z.; Zhang, L.; Huang, Q.; Yang, Y.; Nie, Z.; Cheng, J.; Yang, J.; Wang, Y.; Chao, M. Contamination and risk of heavy metals in soils and sediments from a typical plastic waste recycling area in North China. Ecotoxicol. Environ. Saf. 2015, 112, 343-351. [CrossRef] [PubMed]

4. Lui, L.; Li, W.; Song, W.; Guo, M. Remediation techniques for heavy metal-contaminates soils: Principles and applicability. Sci. Total Environ. 2018, 633, 206-219.

5. Ministry of Environment. White Paper of Environment 2015; Ministry of Environment: Sejong-si, Korea, 2015.

6. Zeng, G.; Zhang, C.; Huang, D.; Lai, C.; Tang, L.; Zhou, Y.; Xu, P.; Wang, H.; Qin, L.; Cheng, M. Practical and regenerable electrochemical aptasensor based on nanoporous gold and thymine- $\mathrm{Hg}^{2+}$-thymine base pairs for $\mathrm{Hg}^{2+}$ detection. Biosens. Bioelectron. 2016, 90, 542-548. [CrossRef] [PubMed]

7. Liu, Y.; Zeng, G.; Zhong, H.; Wang, Z.; Liu, Z.; Cheng, M.; Liu, G.; Yang, X.; Liu, S. Effect of rhamnolipid solubilization on hexadecane bioavailability: Enhancement or reduction? J. Hazard. Mater. 2017, 322, $394-401$. [CrossRef] [PubMed]

8. Song, B.; Zeng, G.; Gong, J.; Zhang, P.; Deng, J.; Deng, C.; Yan, J.; Xu, P.; Lai, C.; Zhang, C.; et al. Effect of multiwalled carbon nanotubes on phytotoxicity of sediments contaminated by phenanthrene and cadmium. Chemosphere 2017, 172, 449-458. [CrossRef] [PubMed]

9. Kim, G.H. Electrokinetic remediation of organic contaminated soil and application of the surfactant. Master's Thesis, University of Chungang, Seoul, Korea, 2001.

10. Lee, B.S. A study on estimation of diffusion range for the contamination ground and ground water for hydraulic model. Master's Thesis, University of Chungang, Seoul, Korea, 2009.

11. Yustres, Á.; López-Vizcaíno, R.; Sáez, C.; Cañizares, P.; Rodrigo, M.A.; Navarro, V. Water transport in electrokinetic remediation of unsaturated kaolinite. Experimental and numerical study. Seperatin Purif. Technol. 2018, 192, 196-204. [CrossRef] 
12. White, A.J.; Bradshaw, P.T.; Herring, A.H.; Teitelbaum, S.L.; Beyea, J.; Stellman, S.D.; Steck, S.E.; Mordukhovich, I.; Eng, S.M.; Engel, L.S.; et al. Exposure to multiple sources of polycyclic aromatic hydrocarbons and breast cancer incidence. Environ. Int. 2016, 80-90, 185-192. [CrossRef] [PubMed]

13. Ministry of Environment. White Paper of Environment 2011; Ministry of Environment: Sejong, Korea, 2011; ISBN 11-1480000-000586-10.

14. Cang, L.; Fan, G.P.; Zhou, D.M.; Wang, Q.Y. Enhanced-electrokinetic remediation of copper-pyrene co-contaminated soil with different oxidants and pH control. Chemosphere 2013, 90, 2326-2331. [CrossRef] [PubMed]

15. Kuppusamy, S.; Palanisami, T.; Megharaj, M.; Venkateswarlu, K.; Naidu, R. In-Situ Remediation Approaches for the Management of Contamiinated Sites: A Comprehensive Overview. Reviews of Environmental Contamination and Toxicology; Springer: Berlin, Germany, 2016; Volume 236, pp. 1-115.

16. Acar, Y.; Alshawabkeh, A. Principles of electrokineties remediation. Environ. Sci. Technol. 1993, 27, $2638-2647$. [CrossRef]

17. Lee, H.S.; Jahng, D.; Lee, K. Electrokinetic transport of an NAPL-degrading microorganism through sandy soil bed. Biotechnol. Bioprocess Eng. 1999, 4, 151-153. [CrossRef]

18. Probstein, R.F.; Hicks, R. Removal of contaminants from soils by electric fields. Science 1993, 260, 498-503. [CrossRef] [PubMed]

19. Puls, R.W.; Powell, R.W. Permeable Reactive Subsurface Barriers for the Interception and Remediation of Chlorinated Hydrocarbon and Chromium (VI) Plumes in Ground Water. In National Risk Management Research Laboratory US EPA Remedial Technology Fact Sheet; USEPA: Washington, WA, USA, 1997.

20. Simon, F.G.; Meggyes, T. Removal of organic and inorganic pollutants from groundwater using permeable reactive barriers: Part 1. Treatment processes for pollutants. Land Contam. Reclam. 2000, 8, 103-116.

21. Lockhart, N. Electroosmotic dewatering of clays, III. Influence of clay type, exchangeable cations, and electrode materials. Coll. Surf. 1983, 6, 253-269. [CrossRef]

22. Alloway, B. Heavy Metals in Soil; John Wiely \& Sons Inc: New York, NY, USA, 1990; pp. 1-990.

23. Han, J.G.; Hong, K.K.; Kim, Y.W.; Lee, J.Y. Enhanced electrokinetic (E/K) remediation on copper contaminated soil by CFW (carbonized foods waste). J. Hazard Mater. 2010, 177, 530-538. [CrossRef] [PubMed]

24. Lee, H.Y.; Park, J.Y.; Kim, S.J.; Lee, Y.J.; Yang, J.W. A study on surfactants foe electrokinetics soil remediation. J. Soil Groundw. Environ. 2003, 8, 1-8.

25. Roh, K.S. A Surfactant Composition for Soil Washing and Method for Soil Remediation Using the Same; Korean Intellectual Property Office: Deajeon, Korea, 1999; ISBN 1002355610000.

26. Narasimhan, B.; Ranjan, R.S. Electrokinetic barrier to prevent subsurface contaminant migration: Theoretical model development and validation. J. Contam. Hydrol. 2000, 42, 1-17. [CrossRef]

27. Kim, Y.W.; Lee, J.Y.; Lee, Y.K.; Han, J.G. Study on Heavy Metals sedimentation by pH. In, Hoengseong in South Korea, October 22-23 Korean Society of Civil Engineers. convention: Tokyo, Japan, 2009; 2037-2040.

28. Elektorowicz, M.; El-Sadi, H.; Lin, J.; Ayadat, T. Effect of supercritical fluid extraction parameters and clay properties on the efficiency of phenanthrene extraction. J. Coll. Interface Sci. 2007, 309, 445-452. [CrossRef] [PubMed]

29. Kang, S.J. Enhancing Desorption and Biodegradation of Polycyclic Aromatic Hydrocarbons Sorbed to biochar: Effect of Using Powdered Biochar and Surfactant. Master's Thesis, Seoul National of Uniersity, Seoul, Korea, 2018.

(C) 2020 by the authors. Licensee MDPI, Basel, Switzerland. This article is an open access article distributed under the terms and conditions of the Creative Commons Attribution (CC BY) license (http://creativecommons.org/licenses/by/4.0/). 